\title{
Spatial features of the development of the economic federalism system in Russia
}

\author{
Natalya Korotina* \\ Chelyabinsk Branch of RANEPA, Komarova Str., 26, 454077 Chelyabinsk, Russia
}

\begin{abstract}
Understanding the spatial features of the development of economic processes of federalism requires understanding the consequences that the formation and implementation of the policy of relations between the federal center and the regions. The goal of our present research is a theoretical justification of the content of the concept of "economic federalism" from the standpoint of a spatial approach. The novelty of the research lies in examining the relations of economic federalism not only within the framework of the state budget system, but also within the framework of interaction between state and market structures. The theoretical and methodological basis of this study is a set of scientific concepts in the field of economic federalism and spatial analysis. The author chose the method of econometric factor analysis for practical confirmation of theoretical concepts. This method made it possible to assess the impact on the level of economic development of the region of indicators of both the budgetary subsystem of economic federalism and the subsystem of interaction between state and market structures. With the help of the calculations, the positioning of the Russian regions was carried out according to the type of the existing economic environment of federalism.
\end{abstract}

\section{Introduction}

The identification of regional features in the study of the problems of federalism is due to the close connection of the state structure of the federal state with its administrativeterritorial division. The last one is the division of the country's territory into component parts, each of which has its own identity, therefore, to understand the features of the system of economic federalism in the Russian Federation, we will focus on the territorial basis for the formation of federalist relations.

Many interpretations and definitions are used to characterize economic federalism in the Russian scientific literature. The terms "budgetary", "fiscal", "tax", "financial", "financial and budgetary", "fiscal federalism" are widely used. On the one hand, this terminological diversity is due to different approaches of researchers to the search for the Russian equivalent of the English-language concept of "fiscal federalism", on the other hand, the complexity of the economic relations that are being considered. There is widespread controversy in Russian scientific publications about the identity or difference of these terms

\footnotetext{
* Corresponding author: korotina-nyu@ranepa.ru
} 
and concepts. The ambiguity of terminology and interpretations is predetermined by the absence of any scientifically accepted and legislatively fixed construction. The legislative consolidation of the term "fiscal federalism", as noted in M. Planck's Encyclopedia of Comparative Constitutional Law, is also not found in any foreign constitutional document [1].

In the Russian scientific literature, the authors studying the economic side of the relations of federalism focus on aspects that are mainly associated with budgetary relations. [2-6].These authors examine the issues of interbudgetary relations in the Russian Federation, the delineation of tax sources of budgets and the establishment of budget restrictions. Another group of authors is actively exploring the spatial factors of the development of federalism relations. [7, 8], others study the specifics of coordinating the interests of the federal center and regions during the implementation of federal policy [9].

In our opinion, despite the use of different terminology, all the scientific works of Russian authors deepen the theory of economic federalism. At the same time, the main scientific controversy comes down mainly to the discussion of the problems of the budgetary system of the federal state, although only financial interaction does not exhaust the entire range of interactions that the system of federalism has on the economic development of regions and requires a deeper understanding of the economic foundations of federal relations.

\section{Methods of determination type of economic federalism environment}

The subject area of economic federalism is not limited to the delimitation of functions and resources in only one area of public administration - the budgetary sphere. In addition to the redistribution of resources, the relationship between the authorities along the vertical and horizontal of the state-territorial structure is aimed at the development of regions, which exists in the "zone of responsibility" of economic federalism.

The author of the article supposes that 1) the term"economic federalism" characterizes the entire spectrum of economic relations in federal states; 2) these relations develop during interaction in the processes of formation and redistribution of functions, spheres of activity, resources of the state in accordance with the constitutional delimitation of competencies between the federation and its subjects; 3 ) represent a set of specific economic relations that reflect the characteristics of the interaction of all participants involved in the implementation of economic processes throughout the federation, that is, in all its regions. Thus, the term "economic federalism" reflects the architecture of economic relations of a federal state.

Economic federalism is directly responsible for the effective functioning of the budgetary sphereand is indirectly responsible for the movement and development of the entire economy by attracting and differentiating all types of economic resources by levels of management, expanding the potential of regions and municipalities, and ultimately leading to market development of territories, contributing to economic growth of each region and the country as a whole. This is achieved through the joint functioning of state and market structures within the framework of the dispersal of state economic resources and resources of the economy that generate the gross social product throughout the country, which, in turn, is divided into the territories of federalism subjects.

Thus, in the author's opinion, the system of economic federalism includes two subsystems: the state budgetary subsystem, which is "responsible" for the dispersal of state power along the vertical hierarchy of the state structure, and the subsystem of interaction between state and market structures, which is "responsible" for horizontal ties and provides spatial connectivity of the country's territory with the aim of its unity. 
To assess the influence of factors of economic federalism on the level of development of the territorial economy, the method of econometric factor analysis is chosen, which consists in an econometric assessment of the mathematical model of the dependence of the level of economic development of a region on factors that influence this level. When choosing a method, the opinion was considered to identify the factors in development of the regional economy; a static concept is more adequate than a dynamic one, because it considers the state at the current time[10].

The gross regional product is used as a generalizing indicator of the level of economic development of the entities of Russian Federation. The following factorial variables were used as independent variables characterizing each of the subsystems of economic federalism(Table 1):

- to characterize the state budgetary subsystem: the share of transfers from the federal budget in regional budget expenditures; returnrate.

- to characterize the subsystem of interaction between state and market structures: the volume of investments coming into the region from the federal budget; the level of geographic connectivity; level of internet communications.

Table 1. Methodology for determining the value of factor variables.

\begin{tabular}{|c|c|c|}
\hline $\begin{array}{l}\text { Characterized } \\
\text { subsystem }\end{array}$ & Factor & Calculation method \\
\hline \multirow{2}{*}{$\begin{array}{l}\text { State } \\
\text { budgetary } \\
\text { subsystem }\end{array}$} & $\begin{array}{l}\text { Share of transfers from the } \\
\text { federal budget in regional } \\
\text { budget expenditures }\end{array}$ & $\begin{array}{l}\text { Ratio of transfers from the federal budget to } \\
\text { the expenditures of the consolidated budget } \\
\text { of the region, } \%\end{array}$ \\
\hline & Return rate & $\begin{array}{l}\text { Ratio of transfers from the federal budget to } \\
\text { the amount of taxes received to the federal } \\
\text { budget collected in the territory of the } \\
\text { analyzed region, coefficient }\end{array}$ \\
\hline \multirow{3}{*}{$\begin{array}{l}\text { Subsystem of } \\
\text { interaction } \\
\text { between } \\
\text { government } \\
\text { and market } \\
\text { structures }\end{array}$} & $\begin{array}{l}\text { The volume of investments } \\
\text { in the region from the } \\
\text { federal budget }\end{array}$ & $\begin{array}{l}\text { The volume of investments in the region } \\
\text { from the federal budget, rubles }\end{array}$ \\
\hline & $\begin{array}{l}\text { Geographic connectivity } \\
\text { level }\end{array}$ & $\begin{array}{l}\text { Density of communication lines, } \mathrm{km} \text {. tracks } \\
\text { per } 10,000 \mathrm{~km}^{2} \text { of territory }\end{array}$ \\
\hline & $\begin{array}{l}\text { Internet communications } \\
\text { level }\end{array}$ & $\begin{array}{l}\text { Number of personal computers, pcs. per } 100 \\
\text { employees }\end{array}$ \\
\hline
\end{tabular}

Due to the different dimensions of the variables, the following form of semilogarithmic regression model was chosen:

$$
\operatorname{lnGRP}_{i}=\text { const }+a_{1} d_{T R i}+a_{2} R_{i}+a_{3} \text { InInvest }_{i}+a_{4} \text { GConnect }_{i}+a_{5} \text { IConnect }_{i},
$$

$i$ - region of the Russian Federation, GRP - grossregionalproduct; $d_{T R}$ - the share of transfer payments from the federal budget in the expenses of the region's consolidated budget; $\mathrm{R}$ - return coefficient; S - splitting factor; Invest -volume of investments in the region from the federal budget; GConnect - geographic connectivity level; IConnect internet communications level.

\section{Analysis of the type of economic federalism environment in Russia}

Analysis of the data showed the presence of a significant relationship between each of the selected variables with the gross regional product. The figure shows the scatter diagrams of the studied variables (Fig.1). 


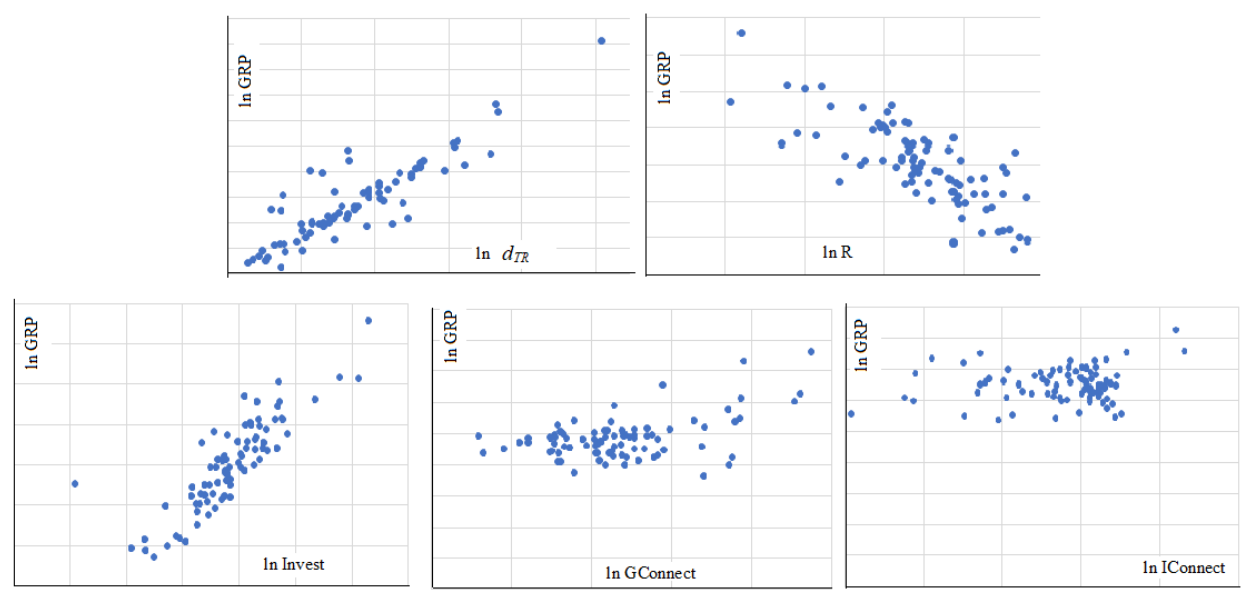

Fig. 1. Scatter diagrams characterizing of the economic federalism system.

The resulting regression model looks the following way:

$$
y=6.8255+3.1778 x_{1}+0.0086 x_{2}+0.3521 x_{3}+0.0362 x_{4}+0.0211 x_{5}
$$

Analysis of the model parameters allows us to conclude the following. With an increase of 0.01 in the share of transfer payments from the federal budget because of changes in vertical relations in the policy of economic federalism, the GRP will increase by 3.187 thousand rubles. With an increase of 0.01 in the coefficient of repayment of funds, the GRP will increase by 8.6 thousand rubles. With an increase of $1 \%$ in investments in main assets of the region coming from the federal budget, the GRP increases by $0.35 \%$. With an increase of $100 \mathrm{~km}$. tracks per $10,000 \mathrm{~km}^{2}$ of the density of routes, GRP increases by $3.6 \%$. With an increase in Internet communications level by one computer per 100 employees, the GRP increases by 21.1 thousand rubles.

The correlation coefficient obtained by calculations is 0.85 , which is higher than $0.7-$ that indicates a close relationship between the features in this population.

We present the positioning of regions according to the type of the existing economic environment of federalism based on the results of the analysis. The positioning is presented in the system "gross regional product - vertical relations of federalism - horizontal relations of federalism".

The positioning criterion was the average value of each indicator, the integral indicators were determined by standardizing to the average Russian level [11]. The vertical relationship of federalism is characterized by the integral indicator of the dispersion of state power in the regions in relation to economic resources, which is determined based on private indicators of decentralization: the share of tax revenues in the revenues of the consolidated budget of the region, the return coefficient, the splitting factor. The horizontal relations of federalism are characterized by the integral indicator of the spatial connectivity of territories, which is calculated based on private indicators of investment in fixed assets from the federal budget in the region, the level of geographical connectivity of the territory, the level of Internet communications in the region.

To assess the type of the current economic environment of federalism, the regions were initially divided into two groups: with a GRP per capita below the Russian average (39 regions) and with GRP per capita above the Russian average (46 regions) (Table 2). 
Table 2. Positioning of regions by the type of federal environment

\begin{tabular}{|c|c|c|c|}
\hline \multirow{2}{*}{\multicolumn{2}{|c|}{ Indicators }} & \multicolumn{2}{|c|}{ Integral indicator of spatial connectivity of territories } \\
\hline & & Lower than the Russian average & Higher than the Russian average \\
\hline \multicolumn{4}{|c|}{ Regions with GRP per capita below the national average } \\
\hline \multirow{2}{*}{ 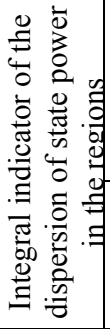 } & $\begin{array}{l}\text { Lower } \\
\text { than the } \\
\text { Russian } \\
\text { average }\end{array}$ & $\begin{array}{l}\text { Ivanovskaja, Kirovskaja, Kostromskaja, } \\
\text { Kurganskaja, Orlovskaja, Penzenskaja, } \\
\text { Pskovskaja, Rjazanskaja, Saratovskaja, } \\
\text { Smolenskaja, Tambovskaja, } \\
\text { Ul'janovskaja }\end{array}$ & $\begin{array}{l}\text { Respubliki: Krym, Severnaja } \\
\text { Osetija - Alanija; oblasti: } \\
\text { Volgogradskaja, Rostovskaja, } \\
\text { Tverskaja; Sevastopol' }\end{array}$ \\
\hline & $\begin{array}{l}\text { Higher } \\
\text { than the } \\
\text { Russian } \\
\text { average }\end{array}$ & $\begin{array}{l}\text { Respubliki: Altaj, Burjatija, Kabardino- } \\
\text { Balkarskaja, Chechenskaja; Omskaja i } \\
\text { Amurskaja oblasti, Evrejskaja } \\
\text { avtonomnaja oblast' }\end{array}$ & $\begin{array}{l}\text { Respubliki: Dagestan, } \\
\text { Ingushetija }\end{array}$ \\
\hline \multicolumn{4}{|c|}{ Regions with GRP per capita above the national average } \\
\hline \multirow{2}{*}{ 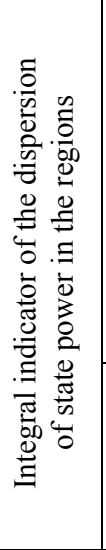 } & $\begin{array}{l}\text { Lower } \\
\text { than the } \\
\text { Russian } \\
\text { average }\end{array}$ & $\begin{array}{l}\text { Respubliki: Bashkortostan, Karelija, } \\
\text { Komi, Udmurtskaja, Hakasija; kraja: } \\
\text { Permskij, Primorskij, Habarovskij; } \\
\text { oblasti: Arhangel'skaja, Astrahanskaja, } \\
\text { Vologodskaja, Irkutskaja, } \\
\text { Kemerovskaja, Kurskaja, Lipeckaja, } \\
\text { Murmanskaja, Sahalinskaja, } \\
\text { Sverdlovskaja, Tul'skaja, Tomskaja, } \\
\text { Tjumenskaja, Cheljabinskaja, } \\
\text { Jaroslavskaja }\end{array}$ & $\begin{array}{l}\text { Respubliki: Tatarstan; kraja: } \\
\text { Krasnodarskij, Krasnojarskij; } \\
\text { oblasti: Belgorodskaja, } \\
\text { Voronezhskaja, Kaluzhskaja, } \\
\text { Leningradskaja, Moskovskaja, } \\
\text { Nizhegorodskaja, } \\
\text { Novgorodskaja, Samarskaja; } \\
\text { Moskva, Sankt-Peterburg }\end{array}$ \\
\hline & $\begin{array}{l}\text { Higher } \\
\text { than the } \\
\text { Russian } \\
\text { average }\end{array}$ & $\begin{array}{l}\text { Respublika Saha, avtonomnye okruga: } \\
\text { Neneckij, Hanty-Mansijskij, Jamalo- } \\
\text { Neneckij, Chukotskij; Kamchatskij kraj; } \\
\text { oblasti: Novosibirskaja, Orenburgskaja, } \\
\text { Magadanskaja }\end{array}$ & Kaliningradskaja oblast' \\
\hline
\end{tabular}

As a result of the analysis, 4 subgroups of regions were identified by the type of federal environment in the group of regions with GRP per capita below the national average:

- a subgroup where both indicators of federalism are lower than the Russian average. These regions are characterized by weak economic development, a low level of transfer of state power to the regional level, and an insufficient level of territorial connectivity. These include 24 regions $(28.2 \%$ of the total).

- a subgroupwith a low level of transfer of state power to the regional level (the integral indicator is lower than the national average), where due to the investment efforts of the federal center, favorable conditions for spatial connectivity (the integral indicator is higher than the national average) have developed: 6 regions, which make up $7.1 \%$ of all regions of Russia.

- a subgroup where the subjects have a higher than the Russian average level of transfer of state power to the regional level, but also have insufficient level of spatial connectivity for the economic development (the integral indicator is lower than the national average): 7 regions or $8.2 \%$.

- a subgroup where both indicators of federalism are higher than the Russian average. High levels of transfer of state power to the regional level and coherence of territories, but insufficient level of economic development to achieve the Russian average characterize these regions. This situation is observed in two regions (2.4\%) - Dagestan and Ingushetia.

Among the regions with a higher than Russian average level of GRP per capita, the following subgroups are distinguished by the type of the existing federal environment:

- a subgroup where both indicators of federalism are lower than the national average, but the high level of development of industrial production allows them to have a high level 
of GRP, despite the high share of the federal center withdrawing taxes collected on the territories of the regions and insufficient provision of conditions for associated development. These include 23 regions or $27.1 \%$.

- a subgroup with a relatively low level of transfer of state power to the regional level (the integral indicator is lower than the national average), where favorable conditions have developed for spatial connectivity (the integral indicator is higher than the national average): 13 regions or $15.3 \%$ of the total number of regions of Russia.

- a subgroup, which subjects have a higher than the Russian average level of transfer of state power to the regional level, but a low level of spatial coherence (an integral indicator below the Russian average level), which are determined by the specifics of industrial production in the indicated regions (the fuel and energy complex industry) and the pursued policy of federalism in relation to them: 9 regions or $10.6 \%$.

- a subgroup with high levels of transfer of state power to the regional level, coherence of territories, and a high level of economic development. There is only one region in this subgroup $(1.2 \%)$ - the Kaliningrad region, which is characterized by a special political and geographical status.

\section{Conclusions}

1. An analysis of the vertical relations of federalism showed a significant regional asymmetry from the standpoint of decentralization: the number of regions with an indicator of the dispersion of state power across regions in terms of economic resources below the average is significantly higher than the number of regions with an indicator above the average.

2. An analysis of the horizontal relations of federalism also reveals significant asymmetries: the spatial connectivity of most Russian regions is below average.

3. This reflects the unevenness in the relationship between the federal center and the regions in both budgetary and economic state functions, which ultimately characterizes the entire structure of the model of economic federalism as unstable, this requires an improvement in the policy of economic federalism for smooth out the asymmetry of spatial differentiation.

\section{References}

1. Max Planck, Encyclopaedia of Comparative Constitutional Law, Oxford University (2020), //oxcon.ouplaw.com/

2. V.V. Bukharskiy, A.M. Lavrov, Public Administration Issues, 1, 7 (2020)

3. A.B. Zolotareva, Economic policy, 5, 90 (2020)

4. V.V.Klimanov, A.I. Safina,Finance, 1, 1 (2020)

5. V.V.Klimanov, A.N.Deryugin, A.A. Mikhailova,V.A.Yagovkina, Scientific reports: economics, Fiscal federalism. Financial participation of regions in achieving national development goals (2019)

6. S.M.Drobyshevskij, N.S. Kostrykina,A.V. Korytin Economic issues, 10, 5 (2020)

7. E.M.Bukhvald, S.D. Valentey,A.V. Odintsova, Bulletin of the Institute of Economics of the Russian Academy of Sciences. 1(2020)

8. A.N. Shvetsov, Federalism, 3(99), 5 (2020)

9. V.V. Levina, Federalism, 1(93), 100 (2019)

10. E.M. Bukhvald,O.B. Ivanov, Stage: economic theory, analysis and practice, 2,7 (2017) 
11. I.Danilova, A.Karpushkina, et al. Innovation Management and Education Excellence through Vision 2020. Proceedings of the 31st International Business Information Management Association Conference (IBIMA), 4082 (2018) 